\title{
Beckett: portraits of the artist in exile
}

\author{
Roisin Kemp and Josephine Loftus
}

Samuel Beckett, Irish ex-patriate, depressive and master dramatist, won the Nobel Prize for Literature in 1969. Two recent biographies (The Last Modernist (1996) by Anthony Cronin and the more sterile Damned to Fame (1996) by Professor James Knowlson) have helped to shed new light on the man and his work. A previous attempt by Deirdre Bair received little input or interest from her subject but is principally known for her exposé of Beckett as a hero of the French resistance, dismissed by the latter as 'boy-scout stuff. Beckett's reluctance to wallow in the limelight is legendary, and both works delineate the complexity of his character and creativity in the usual way: precocity, difficult temperament, fraught relationship with his mother (who suffered from what might be classified as a bipolar disorder, type 2), identity conflicts, ambiguous feelings regarding the homeplace, sensitive, and gauche young man adrift in the world, Cronin's book offers an affectionate and well-paced account which paints a picture of a less tortured man, and does some justice to the warmth of his personality and wicked sense of humour:

From Endgame:

Nagg: (clasping his hands, closing his eyes, in a gabble) Our Father which art-

Hamm: Silence! In silence. Where are your manners? (Pause.) Off we go. (Attitudes of prayer. Silence. Abandoning his attitude, discouraged).

Well?

Cloy: Sweet damn all! (To Nagg). And You!

Hamm: The bastard. He doesn't exdst!

Clov: Not yet.

Knowlson's scholarly tome is better on Beckett's work. Some interesting themes emerge regarding Beckett's decision to write mainly in the language of his adopted domicile, arguably the turning-point of his slow path to fame. This followed a revelation at Killiney harbour on one of his visits back to Ireland, a near fatal stabbing by a Parisian pimp, and his gradual disentanglement from James Joyce's household and influence (there was a cooling-off subsequent to his rejection of Lucia Joyce, who suffered from a psychotic disorder). However, none of the explanations of his decision are wholly satisfactory. Candidate theories must include the liberation of saying good-bye to what's past; the instinctive appeal to his ascetic sensibilities of the discipline involved; and the sensuousness of the French language casting into relief the starkness of his vision. But what of the possibility that there is something in the Irish psyche which is not wholly satisfied by the English language, steering both authors to the occasional neologism? Beckett's solecistic response when asked during an interview if he was an Englishman ('au contraire') is a delicious example of the kind of bar-room absurdities that were his wont. In an article praising Joyce's Work in Progress, later to become Finnegans Wake, he considered the English language as abstracted to death. Certain utterances attributed to the writer convey the faintly mocking self-consciousness of one who is doomed to be mythologised.

Beckett knew many of the leading writers, artists and thinkers of his day, including the existentialist figures, and although he was interested in philosophy, he was himself more drawn to the early Greeks. At one stage as a would-be art critic, he had taken himself to Germany in the immediate pre-war period to study Old Masters, primarily with hopes of being able to make a career of it, but like other schemes, the plan was later abandoned. He fostered friendships with several artists, particularly the van Velde brothers (a scorned mistress, American art patron Peggy Guggenheim, believed him to have a homosexual interest in one of the brothers). One of his most enduring friendships was with the sculptor Giacometti. fellow insomniac and drinking partner around the boulevards of Montparnasse. One of the photographs in Cronin's book shows the famous tree in Giacometti's studio, a model for the main stage prop in Waiting for Godot.

Earlier, while in London, he was psychoanalysised by Bion, and entertained notions that his panic attacks, episodes of depersonalisation, and feelings of suffocation might be linked to uncomfortable recollections of having been conscious inside his mother's womb. For years he suffered from painful boils and eczema sores 
which he came to believe were psychosomatic, or at least that they could be helped by dredging through the subconscious.

\section{From More Pricks than Kicks}

"What ails you?" asked Winnie.

He had allowed himself to get run down, but scoffed at the idea of a sequitur from his body to his mind

As can be imagined for one as introspective as Beckett, analysis was a painful process, and frequently left him more miserable; it seems he recovered more rapidly after the news of his first publication.

Together with his psychiatrist friend, Geoffrey Thompson, he had visited the Royal Bethlem Hospital (cast as the Magdalen Mental Mercyseat in Murphy), and became fascinated by some of the patients, in particular a catatonic young man who spent every day waiting for his mother. dressed in a long coat and hobnailed boots, his legs stretched out in front of him with only his heels resting on the ground.

From Malone Dies:

The man has not yet come home. Home. I have demanded certain movements of my legs and even feet. I know them well, and could feel the effort they made to obey. I have lived with them, that little space and time, filled with drama, between the message received and the piteous response ...

Felix Post's (1994, 1996) recent studies of creativity and psychopathology found that among writers the highest rates of severe affective disorder occurred in poets. Beckett believed passionately in the artistic imperative, that inner drive to create, which he deemed a commandment. He did not discourage people referring to him as a poet. Indeed the first time he reached the headlines (in a French newspaper) it was as such that he was described: 'Irish poet stabbed in Paris, early morning attack'. In fact the only time Cronin's book depicts him as being truly happy is after this incident-a Lazarus propped up in a hospital bed, glasses polished, surrounded by friends, with the double satisfaction of introducing his mother to a solicitous James Joyce, by whom she was undoubtedly impressed. It was also during his stay in hospital that he developed a close relationship with Suzanne Deschevaux-Dumesnils, a former tennis partner, who was later to become his wife and dedicated champion of his work. Beckett's early poetry was frankly poor, both over-allusive and obscure, though recently more lyrical examples have been unearthed:

je voudrais que mon amour meure

qu'il pleuve sur le cimitière

et les ruelles ou je vais

pleurant celle qui crut m'aimer
Actually, he allowed his poetry to be reprinted more frequently than much of his other work. One of the most tender excerpts from his writing comes from Krapp's Last Tape-an old man with memory problems, rewinding an audiotape of his memoirs, shaking up the embers of his life. The scene was probably inspired by Beckett's younger days, punting on a lake in Germany with his first love, Peggy Sinclair, his Jewish first-cousin who died tragically young-the relationship was discouraged by his family for the obvious reasons.

I said again I thought it was hopeless going on and she agreed, without opening her eyes. (Pause). I asked her to look at me and after a few moments (Pause)-after a few moments she did. but the eyes just slits because of the glare. I bent over her to get them open and they opened. (Pause. Low.) Let me in. (Pause). We drifted in among the flags and stuck. The way they went down, sighing before the stem! (Pause.) I lay down across her with my face on her breasts and my hand on her. We lay there without moving, but under us all moved, and moved us, gently, up and down, and from side to side.

Beckett's aquiline features and elegant physique were remarkably photogenic, and the photographs in Knowlson's biography are probably more interesting, apart from one wonderful study in Cronin's taken during a German rehearsal for Godot (the poses in John Minihan's coffee-table collection of portraits seem a little too contrived). Perhaps our favourite photograph is one which is in neither book, taken for the now defunct Irish newspaper the Evening Press during his last visit to Dublin. It was an impromptu shot of an amused Beckett on a Dublin street whose expression betrayed little of the angst for which he is famous. Like Murphy (in Murphy) "se justifier n'était pas son genre". More sceptic than pessimist, the periodic reclusiveness might have also had something to do with the various spongers and hangers-on who prevailed upon his generosity once he achieved a degree of notoriety. The final word should belong to the man who proclaimed "I regret everything":

After all, it is not important not to finish, there are worse things than velleities. But is that the point? guite likely. All I ask is that the last of mine should have living as its theme. that is all. I know what I mean ...

\section{References}

CRONIN, A. (1996) Samuel Beckett: The Last Modernist. London: Harper Collins.

KNOWLSON, J. (1996) Damned to Fame. London: Bloomsbury.

POST, F. (1994) Creativity and psychopathology: a study of 291 world-famous men. British Journal of Psychiatry. 165, 22-34. 
PSYCHIATRY AND THE MEDIA

- (1996) Verbal creativity, depression and alcoholism: an investigation of one hundred American and British workers. British Journal of Psychiatry. 168, 545-555.

*Rosin Kemp, Research Psychiatrist and Honorary Lecturer, Department of Psychological Medicine, King's College Hospital and Institute of

Psychiatry, 103 Denmark Hill, London SE5 8AZ; e-mail: spharak@iop.bpmf.ac.UK and Josephine Loftus, Specialist Registrar, Homerton Hospital. London

*Correspondence

\section{College Seminars Series}

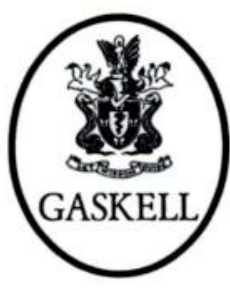

\section{Seminars in Alcohol and Drug Misuse}

\section{Edited by Jonathan Chick and Roch Cantwell}

Psychiatric complications of alcohol and drug misuse must be recognised and treated confidently. This book provides information to meet the needs of practising psychiatrists and will be useful to physicians, psychologists and social workers. A clear review of the aetiology, epidemiology, treatment and prevention of dependence on and misuse of alcohol and illicit and prescribed drugs is presented. With a balance of theory, recent research and practical clinical guidelines, the book covers specific and common problems in mental health as well as in general medicine. EI 3.50, 1994, 256pp. ISBN 0902441702

Available from good bookshops and from the Publications Department, Royal College of Psychiatrists, 17 Belgrave Square, London SWIX 8PG. Credit card orders can taken over the telephone $(+44(0) 171-2352351$, extension 146). 